\title{
Keeping The Physical Educator "Connected" An Examination Of Comfort Level, Usage And Professional Development Available For Technology Integration In The Curricular Area Of Physical Education
}

\author{
Megan Adkins, University of Nebraska-Kearney, USA \\ Matthew R. Bice, University of Nebraska-Kearney, USA \\ Vicki Worrell, Emporia State University, USA \\ Nita Unruh, University of Nebraska-Kearney, USA
}

\begin{abstract}
Schools continue to integrate the use of technology, and gymnasiums are not an exception. The purpose of the study was to determine the comfort level of Physical Education teachers integrating technology in the gymnasium, determine types of professional development provided for technology use, and potential barriers associated with technology usage. A survey of 179 practicing Physical Education teachers located in the Midwest completed an online questionnaire. Results indicated Physical Education teachers were comfortable integrating technology but reported inadequate professional develop on technology device implementation. These findings suggest Physical Educators are willing to integrate technology but the professional development and resources available to accomplish this is lacking. Future research should examine PETE program offerings, and additional PD opportunities offered by SHAPE America within the area of technology and Physical Education.
\end{abstract}

Keywords: Physical Education, Technology; Technology Integration; Comfort Level

\section{INTRODUCTION}

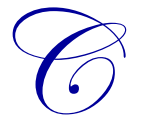

hildren in the United States today are fundamentally different in the way they think, access, interpret, process, interact, and communicate. One potential integral influence is due to digital technologies available to youth. Changes in children and advancement in technology design have drastically altered the educational environment. The federal program, Enhancing Education Through Technology (EETT), developed by the United States Department of Education, supports improving student academic achievements through the use of educational technology (U.S. Department of Education, 2009). As a result, schools across the U.S. request teachers to complete professional development to assist in teachers understanding how to integrate technology in their classrooms to increase student learning (Zemelman, Daniels, \& Hyde, 2005; Snyder, Tan, \& Hoffman, 2005; Kulinna, McCaughtry, Martin, Cothran, \& Faust, 2008; Martin, McCaughtry, Kulinna, Cothran, \& Faust, 2008).

Opportunities to engage students with technologies are not limited to in classrooms but can expand to various areas within the constraints of the school environment. With advancements in mobile technology, Physical Education courses have become a curricular area that students are given the opportunity to utilize digital components in a physically active atmosphere. The Society of Health and Physical Educators of America (SHAPE America) currently provide numerous position statements addressing appropriate practices of technology use in Physical 
Education settings. Subsequently, numerous articles have been published describing technologies available, appropriate practice, and strategies that should be used to implement technology successfully into Physical Education (Casey, Goodyear, \& Armour, 2016; Eberline, \& Richards, 2013; NASPE, 2009; Lee, Burgeson, Fulton $\&$ Spain, 2007; NASPE 2004; NASPE 2007; NASPE 2009a).

School and district professional development opportunities related to technology offered for all teachers in the building many times lack relevance for the Physical Educators due to the difference in class structure and ways technology is used within Physical Education. The purpose of this article was to determine practicing Physical Educator's comfort level of using and integrating technology, and barriers they are encountering. In addition, the article provides knowledge about the means to how Physical Educators receive their professional development, and the resources utilized to be provided the professional development needed in relation to technology integration in the gymnasium.

\section{METHODS}

Study participates were offered, via email, solicitation to participate in the study if they were members of the Central District Society of Health and Physical Educators (CDSHAPE). Participants eligible to participate in the study included teachers from NE, IA, SD, ND, KS, WY, CO who had taught at least one year, and the majority (51\%) of their teaching time was within the area of Physical Education. $(n=2,212)$. The research team was granted access to send the survey through CDSHAPE email through the Institutional Review Board by the participating university and by receiving approval from CDSHAPE. Quantitative data were collected using a questionnaire administered through Qualtrics, an online questionnaire system housed by the university. Participants were emailed the research study cover letter, a description of the purpose of the study, and a link to the questionnaire. Participants were notified participating was completely voluntary, and they could withdraw from the study at any time. The university Institutional Review Board approved all procedures and protocols, before data collection commenced. All CDSHAPE members were provided a follow up reminder to participate in the study two weeks after the initial email was sent out.

\section{SURVEY}

Questions developed for the survey were aligned with the National Education Technology for Teacher (NET-T) standards, and related to the SHAPE America position statement on technology. Professors from two Universities with degrees in Physical Education, Sport Administration, and Instructional Technology reviewed the instrument and evaluated the content, construct, and flow. CDAHPERD and the SHAPE America reviewed the content of the questions and the researchers made revisions per the association request. The Qualtrics survey consisted of layers of questions developed to ask queries pertaining to the Physical Educators response to survey question number one that stated, "Do you use any form of technology for instructional purposes in your Physical Education classroom?" If the responder selected "no," then the Physical Education teacher was directed to answer questions regarding a) why they were not using technology, b) type of professional development training they would prefer in regards to technology, c) thoughts on the potential for technology in the physical education classroom, and d) demographic information.

If the responder answered, "yes" to the initial question, the Physical Educator responded to questions relating to their a) comfort and preparation level in using technology in the classroom, b) proficiency level in a using a variety of technologies, c) technology equipment being used and mobile tablet apps, d) use of online technology, e) type of professional development training they would prefer in regards to technology, f) thoughts on the potential for technology in the physical education classroom, and g) demographic information. A 5-point Likert style scale [strongly agree (SA), agree (A), neutral $(\mathrm{N})$, disagree (D), strongly disagree (SD)] was used to analyze the participant's survey responses whether the participant answered the first question "yes," or "no". Following data collection, survey responses were uploaded and analyzed in SPSS, Version 20.

\section{DATA ANALYSIS AND RESULTS}

Descriptive statistics concerning demographics included gender of participant, teaching experience (years taught) and grade level taught from the previous year. Frequency and percentages were analyzed for demographic data by 
gender (male/female), school level (elementary, middle, high school), teaching experience (1-5, 6-10, 11-15, 16+ years), and size of school (by number of students: less than 200, 201-500, 501-800, 801-1100, 1101+). Variables analyzed included: comfort level integrating technology, technology barriers, professional development available, and how the teacher preferred to receive the professional development. All components other than demographic questions were analyzed on a 5-point Likert style scale [strongly agree (SA), agree (A), neutral (N), disagree (D), strongly disagree (SD)]. The statistical analysis used to determine these outcomes were empirical sound descriptive notations, relationship correlations, and T-Tests. Significant alpha level was established at 0.05 .

A total of 179 teachers participated in the current study; $70.3 \%(\mathrm{n}=128)$ female and $29.7 \%(\mathrm{n}=54)$ male. Teachers represented elementary schools $(K-5) 57 \%(n=92)$, middle schools $\left(6^{\text {th }}-8^{\text {th }}\right.$ grade $) 18 \%(n=29)$, and secondary schools $\left(9^{\text {th }}-12^{\text {th }}\right.$ grade) $25 \%(\mathrm{n}=40)$. Physical Educators who taught $51 \%$ or more of their teaching in Physical Education ranged in years of experience; $1-5$ years $10.1 \%(n=18), 6-10$ years $10.6 \%(n=19), 11-15$ years $13.4 \%$ $(\mathrm{n}=24)$, and 16 or more years $65.9 \%(\mathrm{n}=118)$.

Data collected indicated a result that Physical Education teachers felt comfortable with technology use in their classroom; $87.7 \%$ reported to agree that they felt comfortable integrating technology in existing student activities and $80 \%$ agreed that they were comfortable with the knowledge base of how to use the technology that was available at their school (See Table 1). However, over $45 \%$ reported that they had not received adequate professional development on technology devices and usage. Teachers with $16+$ years of experience reported to have the most difficulty in integration and technology knowledge represented by higher discomfort levels compared to teachers with less experience. Furthermore, Physical Education teachers with 6-10 years of experience noted higher discomfort levels concerning the lack of professional development and adequate resources for technology use (See Table 2).

Table 1. Teacher Comfort Level with Technology Use in Classroom

\begin{tabular}{|c|c|c|c|c|c|}
\hline & & $\begin{array}{c}\text { Strongly Agree } \\
n(\%)\end{array}$ & $\begin{array}{l}\text { Agree } \\
n(\%)\end{array}$ & $\begin{array}{c}\text { Disagree } \\
(\%)\end{array}$ & $\begin{array}{c}\text { Strongly Disagree } \\
n(\%)\end{array}$ \\
\hline \multirow{4}{*}{ Comfort } & Integration & $58(31)$ & $106(56)$ & $22(11.8)$ & $1(.5)$ \\
\hline & Tech knowledge & $40(21.5)$ & $109(58)$ & $37(19.9$ & - \\
\hline & Professional training & $25(13.4)$ & $73(39)$ & $77(41.4)$ & $11(5.9)$ \\
\hline & Resources & $26(14)$ & $93(50)$ & $56(30.1)$ & $11(5.9)$ \\
\hline
\end{tabular}

Table 2. Physical Education Teacher Comfort Level and Preparedness to utilize technology

\begin{tabular}{|c|c|c|c|c|c|c|}
\hline Experience & & $\begin{array}{c}\text { Combined } \\
M(S D)\end{array}$ & $\begin{array}{l}1-5 \text { yrs. } \\
M(S D)\end{array}$ & $\begin{array}{c}\text { 6-10 yrs. } \\
M(S D)\end{array}$ & $\begin{array}{c}11-15 \text { yrs. } \\
M(S D)\end{array}$ & $\begin{array}{c}16+ \\
M(S D)\end{array}$ \\
\hline \multirow{2}{*}{ Comfort } & Integration & $1.82+0.66$ & $1.71+0.61$ & $1.63+0.62$ & $1.63+0.68$ & $1.89+0.67$ \\
\hline & Knowledge & $1.98 \pm 0.66$ & $1.79 \pm 0.58$ & $1.88 \pm 0.72$ & $2.00 \pm 0.67$ & $2.01+0.68$ \\
\hline \multirow{2}{*}{ Preparedness } & Professional development & $2.40+0.83$ & $2.29+0.83$ & $2.56+0.81$ & $2.21+0.71$ & $2.44+0.84$ \\
\hline & Resources & $2.28+0.81$ & $2.21+0.89$ & $2.50+0.82$ & $2.05+0.62$ & $2.28+0.79$ \\
\hline
\end{tabular}

Physical Education teachers reported classrooms with technology motivated students, aids student learning by providing visual feedback, and tutorials, assists in providing a more efficient classroom, and increases moderate to vigorous physical activity time. As many teachers agreed that technology was a necessity, barriers were present. The most noted barriers for technology integration within the classroom included funding $(41.02 \%)$, resources $(20.51 \%)$, not interested in technology $(12.82 \%)$, other $(17.54 \%)$. To follow this question, the researchers asked the entire survey population what would be the most preferred means to deliver professional development about the use of technology in the field; the most preferred means was by face-to-face workshops $(58.95 \%)$, followed by webinars $(32.5 \%)$.

\section{DISCUSSION}

Technology can be implemented in some areas to assist teachers within Physical Education: unit and lesson plan preparation; classroom management; communication with parents and students; instruction and feedback; and assessment. Technology can also enhance student learning, and be a motivator for students. If the teacher does not 
feel comfortable or has limited access to learn about the use or new technologies because of few professional development opportunities, or lack of funding schools need to address this issue.

The U.S. Congress passed the Every Student Succeeds Act (ESSA) in December 2015, reauthorizing the Elementary and Secondary Education Act. Physical Education is included in ESSA as part of a student's "well-rounded" education. The passing of ESSA, states and school districts will have access to significantly more funds to help Physical Education programs with the purchasing of technology equipment and additional relevant professional development experiences.

Resources for Physical Education teachers are becoming more prevalent through SHAPE America resources and technology based Physical Education webinars/conferences developed by practicing Physical Education teachers with a passion for technology. Although these are available Physical Educators surveyed preferred online, face-toface professional development. The survey results suggests that a series of training or blended training would best serve physical education teachers to help defer costs but also have the personal feeling teachers are looking for. A face-to-face meeting could potentially be a great option for first-time technology users followed by webinars or online courses as supplemental training. With mobile technologies readily available, Physical Education classes have the potential to utilize technology and provide an avenue for students to learn how to monitor, assess, and carry out a healthy lifestyle for a lifetime on their own.

\section{LIMITATIONS AND FUTURE RESEARCH}

Limiting factors for this study were population size, time of year the survey was emailed to prospective participants, and participant responses were feeling the need to be socially desirable, rather than truthful. Surveys were emailed to members of Central District SHAPE only, limiting the demographic region of teacher responses. The survey was emailed during the school day during the first semester, which may have potentially limited the sample size. Lastly, socially desirable responses, such as the tendency not to report low levels of technology use, were potential limitations of this study. Future research should examine the technology preparation courses Physical Education Teacher Education (PETE) Universities, and Colleges are currently requiring/offering for Physical Education majors to develop to teach students about the technologically integrated classroom. Additional research should also collect and analyze current professional development opportunities offered at the national, district, and state level for Physical Educators and determine cost, relevance, and population of teachers participating in these events via online and face-to-face.

\section{CONCLUSION}

Technology is constantly changing and evolving, continued training at the school, district, state, and national level is valuable to technology implementation for teachers of all ages and experience but need to be more relevant to the curriculum area. According to Zemelman et a. (1998), when teachers become more competent with the technology available, then their effectiveness is increased, and thus yields enhanced student learning. Despite the roadblocks, a partnership of technology and Physical Education is workable and beneficial for all involved. Frustrated by early failures with technology, many physical educators may give up or under-utilize technology just to say they are using it. The ability to understand technology may appear to some a natural-born trait; however, just like the acquisition of any skill-related endeavor in Physical Education, time on task makes the difference thus specific, related professional development could be the main factor in implementation for the teachers. Once the Physical Educator invests the time and effort to learn technology, teachers who use it for unit and lesson plan preparation, classroom management, communication with parents and students, instruction and feedback, and assessment can save enormous amounts of time and energy helping schools gain teachers who conduct quality Physical Education classes.

\section{AUTHOR BIOGRAPHIES}

Megan Adkins, Ph.D. is an Associate Professor, and program chair for the Health and Physical Education program in the Kinesiology and Sport Science Department at the University of Nebraska-Kearney. Megan began her career as a middle school Physical Education teacher for eight years. She received her Masters in teacher education with 
an emphasis in special population in Physical Education while in the public school system. Megan began teaching at the collegiate level in 2008 when she also pursued her terminal degree and received a $\mathrm{PhD}$ in the area of teacher education with an emphasis in instructional technology in 2011.

Matthew R. Bice, Ph.D. is an Assistant Professor in the Exercise Science program in the Kinesiology and Sport Science Department at the University of Nebraska- Kearney. He completed his undergraduate and graduate degree in the area of Kinesiology at the University of Texas of the Permian Basin. He graduated with his PhD in the area of Public Health Education from Southern Illinois University- Carbondale in 2013.

Vicki Worrell, Ph.D. is a professor at Emporia State University in the Health, Physical Education, and Recreation Program. She taught elementary physical education in Derby and Augusta, KS for 19 years prior to moving to teaching at the collegiate level. Her professional involvement includes having served as President of the American Alliance for Health, Physical Education, Recreation and Dance (AAHPERD, now named SHAPE America), President of the Central District Association for Health, Physical Education, Recreation and Dance (CDAAHPERD), and President of the Kansas Association for Health, Physical Education, Recreation and Dance (KAHPERD).

Nita Unruh, Ph.D. is the department chair for the Kinesiology and Sport Science department, and program coordinator for the Sport Administration program at the University of Nebraska- Kearney. She received her undergraduate degree in the area of Sport Administration from Henderson State University. She then completed her masters at Florida State University in the area of Sports Administration. She continued her educational career by attending the University of Arkansas where she received her EdD in the Sports Administration program.

\section{REFERENCES}

Casey, A., Goodyear, V.A, \& Armour, K.M., (2016) Rethinking the relationship between pedagogy, technology, and learning in health and physical education. Sport, Education and Society, 22(2), 288-304.

Eberline, A.D., \& Richards, K.A. (2013). Teaching with technology in physical education. Strategies, 26(6), 38-39.

Kulinna, P.H., McCaughtry, N., Martin, J.J., Cothran, D., \& Faust, R. (2008). The influence of professional development on teachers' psychosocial perceptions of teaching a health related physical education curriculum. Journal of Teaching in Physical Education, 27, 292-307.

Lee, S. M., Burgeson, C. R., Fulton, J. E., \& Spain, C. G. (2007). Physical education and physical activity: Results from the School Health Policies and Programs Study 2006. Journal of School Health, 77(8), 435-463.

Martin, J.J., McCaughtry, N., Kulinna, P., Cothran, D., \& Faust, R. (2008). The effectiveness of mentoring-based professional development on physical education teachers' pedometer and computer efficacy and anxiety. Journal of Teaching in Physical Education, 27, 68-82.

National Association for Sport and Physical Education (2004). Moving into the future: National standards for physical education (2nd edition). Reston, VA: National Association for Sport and Physical Education.

National Association for Sport and Physical Education (2007). Initial guidelines for online physical education: A position paper from the National Association for Sport and Physical Education. Reston, VA.: Author.

National Association for Sport and Physical Education (2009). Appropriate use of instructional technology in physical education [Position statement]. Reston, VA: Author

National Association for Sport and Physical Education (2009a). Appropriate Instructional Practice Guidelines for Elementary Physical Education Reston, VA: Author.

Snyder, T.D., Tan, A.G., and Hoffman, C.M. (2006). Digest of Education Statistics 2005 (NCES 2006-030). U.S. Department of Education, National Center for Education Statistics. Washington, DC: U.S. Government Printing Office.

Zemelman, S.H., Daniels, H., \& Hyde, A. (2005). Best practice: Today's standards for teaching and learning in America's schools- $3^{\text {rd }}$ Edition. Portsmouth, NH: Heinemann. 
NOTES 